\title{
Instructional Videomodeling to Teach Mothers of Children with Autism to Implement Discrete Trials: A Systematic Replication
}

\author{
Adriano Alves Barboza*,1,2 \\ Orcid.org/0000-0003-3042-1677 \\ Lidiene Camila Barbosa Costa ${ }^{1,2}$ \\ Orcid.org/0000-0002-7390-3476 \\ Romariz da Silva Barros ${ }^{1,2}$ \\ Orcid.org/0000-0002-1306-384X \\ ${ }^{1}$ Universidade Federal do Pará, Belém, PA, Brasil \\ ${ }^{2}$ Instituto Nacional de Ciência e Tecnologia sobre Comportamento, Cognição e Ensino,
}

São Carlos, SP, Brasil

\begin{abstract}
The high number of Autism Spectrum Disorder's (ASD) cases determines a great need for specialized service for this population. This is particularly critical, considering the intensity required according to the specialized literature. Parental training may be an affordable alternative to provide this intervention with a high integrity and less costs, and tools such as videomodeling may facilitate the efficiency of such training procedures. This work aimed to evaluate, with strict experimental control, the efficiency of instructional videomodeling while training parents of children with ASD to implement Discrete Trial Instruction. Three mother-child dyads participated: Beatriz (27 years) and Luan (3 years); Eliana (30 years old) and Igor ( 2 years old); Vanessa (40 years old) and Daniel (4 years old). The results showed an increase in the performance accuracy of all mothers in the application of discrete trials, with an average duration of 4 hours. It is possible that this type of instructional tool has an effect on motivation and broadly promotes access to training contingencies, unlike the limitations of face-to-face training. However, it is important to emphasize that this tool only reaches its full function if it is inserted within a broader training program.
\end{abstract}

Keywords: Parental training, discrete trial instruction, instructional video modeling, Autism Spectrum Disorder.

* Mailing address: Rua Augusto Corrêa, s.n., Laboratório de Psicologia Experimental, sala 02, Guamá, Belém PA, Brazil 6600000. Phone: (82) 9 9959-3350. E-mail: adrianobarboza1@gmail.com

Este trabalho foi realizado com o apoio do Conselho Nacional de Ciência de Tecnologia - CNPq (Processo \#141921/2015-3) e da Coordenação de Aperfeiçoamento de Pessoal de Nível Superior - CAPES (Processo PDSE \#88881.132322/2016-01) para o primeiro autor. O trabalho é parte do programa de pesquisas do Instituto Nacional de Ciência e Tecnologia sobre Comportamento, Cognição e Ensino (INCT/ECCE), financiado pelo CNPq (Processos \#573972/2008-7 e \#465686/2014-1) e pela Fundação de Amparo à Pesquisa do Estado de São Paulo - FAPESP (Processos \# 08/57705-8 e \#2014/50909-8). 


\title{
Utilizando Videomodelação Instrucional para Ensinar Mães de Crianças Diagnosticadas com Autismo a Implementar Tentativas Discretas: Uma Replicação Sistemática
}

\begin{abstract}
Resumo
O elevado número de casos de Transtorno do Espectro do Autismo (TEA) determina uma grande necessidade de atendimento adequado a essa população. Isso é particularmente crítico, considerando a intensidade necessária recomendada na literatura especializada. A intervenção parental pode ser uma alternativa para proporcionar acesso a uma intervenção de qualidade e economicamente acessível, e recursos como a videomodelação podem auxiliar a eficiência deste tipo de treinamento. Este trabalho teve como objetivo avaliar, através de rigoroso controle experimental, a eficiência da videomodelação instrucional no treinamento parental para implementar ensino por tentativas discretas. Participaram deste estudo três díades mãe-criança: Beatriz (27 anos) e Luan (3 anos); Eliana (30 anos) e Igor (2 anos); Vanessa (40 anos) e Daniel (4 anos). Os resultados mostraram aumento na precisão de desempenho de todas as mães na aplicação de tentativas discretas, com duração média de carga horária de treinamento em torno de 4 horas. É possível que esse tipo de ferramenta tenha efeito sobre a motivação e promova amplamente o acesso a contingências de treinamento, diferentemente das limitações de treinamentos presenciais. Porém é importante enfatizar que essa ferramenta só atinge sua plena função se estiver inserida dentro de um programa mais amplo de treinamento.
\end{abstract}

Palavras-chave: Treinamento parental, ensino por tentativas discretas, videomodelação instrucional, Transtorno do Espectro do Autismo.

\section{Videomodelado Instruccional para Enseñar a Madres de Niños Diagnosticados con TEA la Implementación de Ensayos Discretos: Una Replicación Sistemática}

\section{Resumen}

El alto número de casos de Trastorno del Espectro Autista (TEA) determina una gran necesidad de servicios especializados para esta población. Esto es particularmente crítico, considerando la intensidad requerida según la literatura especializada. Entrenamiento de genitores puede ser una alternativa económica para proporcionar este tipo de intervención con alta integridad y a un menor costo, y procedimientos tales como videomodelado instruccional pueden facilitar sua eficiencia. El presente trabajo tiene como objetivo evaluar, a través de un riguroso control experimental, la eficiencia del videomodelado instruccional en genitores de niños diagnosticados con TEA para la implementacion de aprendizaje por ensayos discretos. Participaron tres díadas entre madres y niños: Beatriz (27 años) y Luan (3 años); Eliana (30 años) y Igor (2 años); Vanessa (40 años) y Daniel (4 años). Los resultados mostraron un aumento en la precisión del rendimiento de todas las madres en la aplicación de ensayos discretos, teniendo en cuenta que el entrenamiento dado duro un total de 4 horas en promedio. Es posible que este tipo de herramienta de instrucción tenga un efecto sobre la motivación de genitores y promueva su acceso a este modelo, en contraste con las limitaciones de un entrenamiento presencial. Sin embargo, es importante enfatizar que esta herramienta solo alcanza su función completa si se inserta dentro de un programa de capacitación más amplio.

Palabras clave: Entrenamiento parental, instrucción de ensayos discretos, videomodelación instrucional, Trastorno del Espectro Autista. 
Based on data from the Centers for Disease Control and Prevention, Autism Spectrum Disorder (ASD) is one of the most prevalent development disorders worldwide, affecting 1 of 59 children aged 8 years old (Baio et al., 2016). Specialized treatment is urgently needed for this population. Applied Behavior Analysis (ABA) is the scientific basis for treatments that are the most effective (National Autism Center, 2009).

The effectiveness of behavioral interventions is widely recognized (National Autism Center, 2009). Particularly in cases with more severe impairment, the success of intervention relies on several core characteristics: intensity of intervention (between 30 and 40 hours per week), onset of intervention (beginning at $\sim 2$ years old), duration of intervention $(\sim 2$ years), and comprehensiveness of intervention (multiple environments and multiple teaching targets; Lovaas, 1987; Sallows \& Graupner, 2005). However, the prescribed intensity and costs that are associated with these types of interventions often make it inaccessible for a large proportion of the affected population, particularly in developing countries that have little governmental support, such as Brazil (Barboza, Silva, Barros, \& Higbee, 2015).

Parent- and caregiver-implemented interventions (O’Dell, 1974) may play an important role in applying ABA to a wider proportion of the population. The number of well-trained professionals is currently insufficient to fully implement such interventions with the prescribed intensity and duration. The participation of well-trained parents and caregivers in interventions may increase efficiency, thus allowing behavior analysts to provide services to a larger number of cases that focus on assessing the child's repertoire, building teaching programs, and assessing progress, including the assessment of both the children's performance and implementation integrity.

Experimental research on the effectiveness of caregiver- and parent-implemented interventions is only incipient in Brazil (Barboza et al., 2015; Borba, 2014; Faggiani, 2014; Ferreira, Silva, \& Barros, 2016). Parents and caregivers have been taught to implement teaching programs, with the primary goal of improving intervention outcomes by increasing intensity and generalization to new environments and people. Such studies have explored the potential of caregivers as intervention agents, based on the fact that they have access to the children for more hours than any professional, as a way to increase intervention intensity without increasing financial cost.

Therefore, the continual development of training procedures that allow parents and caregivers to proficiently implement interventions is a fundamental goal. Systematic research on the efficiency of different training procedures to increase parents' and caregivers' implementation accuracy is needed. Research also needs to focus on the effects of these interventions on children's behavior. The present study was an extension of previous studies in our laboratory that focused on the effects of teaching procedures on parents' and caregivers' implementation accuracy.

Borba (2014) previously showed the effectiveness of a parent-implemented intervention for children with developmental delays in Brazil. Although effective, the intervention that was implemented by parents required many hours of training, particularly at the beginning of the process. Focusing on this issue, Faggiani (2014) designed and implemented an online tutorial to teach undergraduate students (Study 1) and a man who completed high school (Study 2) how to conduct a discrete-trials procedure. The tutorial included theoretical training, video modeling, the observation of correction procedures, and error checking. Eight of nine participants reached the implementation accuracy criterion. Other researchers have also proposed teaching tools to optimize training efficiency (e.g., Fazzio, 2007; Marcus \& Wilder, 2009; Nelson-Head, Hill, \& Flores, 2012; Nielsen, Sigurdsson, \& Austin, 2009; Plavnick \& Ferreri, 2011; Pollard, Higbee, Akers, \& Broadhead, 2014; Vladescu, Carroll, Paden, \& Kodak, 2012).

Among the various training tools, video modeling has been widely used as an intervention tool (Catania, Almeida, Liu- 
Constant, \& DiGennaro-Reed, 2009; Horrocks, 2010; Nielsen et al., 2009; Pollard et al., 2014; Vladescu et al., 2012). Such tools have shown promise in reducing the necessity of the presence of a behavior analyst during initial training and reducing the cost of parent-implemented interventions.

Barboza et al. (2015) reported success in training caregivers to conduct a discrete-trials procedure using instructional video modeling. Three parents participated in the study. After watching the training videos, all of the parents reached at least $80 \%$ accuracy in implementing the discrete-trials program. The necessary workload to reach such an outcome was 5 hours, including video modeling and the presence of the behavior analyst. The instructional video modeling procedure was demonstrated to be effective and efficient in training parents of children with ASD.

These studies (e.g., Barboza et al., 2015) must be replicated with the goal of verifying external and internal validity of the findings. For example, the experimental design was an imperfect implementation of the multiplebaseline design. The participants were given a similar number of baseline sessions (four or five) before the independent variable was manipulated, thus making the experimental design closer to an $\mathrm{AB}$ design. Replicating the findings of Barboza et al. (2015) with a more rigorous experimental design will increase internal and external validity of the findings. More empirical evidence of the efficiency of video modeling technology is needed.

The present study continued the line of investigation of Barboza et al. (2015) by evaluating the efficiency of instructional video modeling as a tool for parental training. We employed rigorous experimental controls to evaluate the effects of instructional video modeling on the implementation accuracy of a discrete-trials procedure by parents of children who were diagnosed with ASD. For ethical reasons, when instructional video modeling was insufficient for producing high implementation integrity, feedback was introduced as a remediation procedure. We assessed the time that was necessary to achieve the training goals as a way to measure training efficiency.

\section{Method}

\section{Participants}

Three mother-child dyads participated in the study: Beatriz (27 years old) and her son Luan (3 years old), Vanessa (40 years old) and her son Daniel (4 years old), and Eliana ( 30 years old) and her son Igor (2 years old). To maintain anonymity, these are not the participants' real names. Beatriz and Eliana completed undergraduate education, and Vanessa completed high school. All of the children were diagnosed with ASD by professionals in the Brazilian public healthcare system. Participation was conditional on explicit agreement by signing an informed consent form. This research was approved by the Health Sciences Institute Research Ethics Committee at the Federal University of Pará (technical report no. 175.303, December 14, 2012).

\section{Facilities}

The research was conducted in a $12.5 \mathrm{~m}^{2}$ room $(2.5 \mathrm{~m} \times 5.0 \mathrm{~m})$ at the APRENDE Project, located at the Nucleus of Theory and Research on Behavior, at the Federal University of Pará, Brazil. The room was divided in half by a wall with a unidirectional mirror so that the participants could be observed without seeing the experimenter. One table and two chairs were positioned in the room so that the mother and child could sit down facing each other. There was also one side chair for the experimenter.

\section{Apparatus}

The sessions were recorded using a 14-megapixel Sony Handycam camera. Data sheets, a clipboard, blank paper, a pen, and paper sheets with written instructions were used. During the sessions, five edibles and five toys were used as potential reinforcers.

The Verbal Behavior Milestones Assessment and Placement Program (Sundberg, 2014) was used to determine which teaching programs would be implemented with the children in 
the generalization phase (the only moment at which the parents implemented the intervention with their children). The programs that were implemented in the baseline and treatment phases included Motor Imitation (Program 1) and Intraverbal Using Personal Information (Program 2).

\section{Experimental Design}

A nonconcurrent multiple baseline across participants design (Watson \& Workman, 1981) was used to assess the effects of the independent variable (instructional video modeling) on the dependent variable (implementation accuracy of discrete-trials procedure by parents).

\section{Procedure}

This study was divided into the following five phases:

Phase 1: Baseline. In each session, the participants were provided (1) a paper with instructions about the program to be implemented (i.e., general teaching goal, response required [vocal or motor], and how to record independent, prompted, and incorrect responses), (2) data sheet, (3) pen, (4) five toys, and (5) five edibles. The participants were asked to implement, the best possible way, five discrete trials for each teaching program. At this moment of the baseline phase, none of the participants' questions were answered by the researcher. The teaching programs were then implemented with a confederate (i.e., an experimenter who played the role of a child with atypical development, presenting correct and incorrect responses according to a predetermined list) to avoid inaccurate implementation with the children. According to the multiple-baseline design, each participant was given a different number of baseline sessions.

Phase 2: Intervention. The independent variable was implemented in different scheduled sessions for each participant according to the experimental design and considering performance stability. The participants in the intervention phase were individually taken to a separate room to watch three instructional videos. The videos were the same as those used by Barboza et al. (2015) which combined instructions, visual demonstrations, highlights, and instructional subtitles. The videos focused on skills that were necessary to implement the discrete-trials teaching programs, including (1) how to conduct discrete trials (a general view of the procedure), (2) how to conduct prompting procedures (ways of prompting a student while conducting discrete trials), and (3) how to implement correction procedures (how to perform error correction). Before watching the videos, the participants were instructed on how to use the computer. They were also provided a blank paper so they could take notes. The participants watched the videos as many times as they thought necessary. No feedback was provided in the intervention phase.

Phase 3: Post-video modeling. After watching the videos, the same materials as in Phase 1 were provided, as well as the same instructions. If implementation accuracy was less than $80 \%$, then the participants underwent one more video modeling session. If performance still did not reach the accuracy criterion (80\%) after three video modeling sessions, then the participant was provided Level 1 feedback (i.e., verbal instructions on how to implement the procedural steps that the participant was not implementing correctly). If the participant still did not reach the accuracy criterion after three sessions of Level 1 feedback, then Level 2 feedback (i.e., role-playing with immediate feedback) was provided.

Phase 4: Generalization. When the $80 \%$ performance criterion was reached in two consecutive sessions or when the participant performed at $100 \%$ accuracy in one session, a generalization session was conducted. In this session, the participant implemented discrete trials of a new program with her child. The teaching program was selected from the pool of programs that were defined for that child based on clinical priorities. In this phase, performance generalization was assessed in the context of implementing a new teaching program, which was not part of the formal training. 
Phase 5: Follow-up. One month after the last generalization session, a follow-up session was conducted to check performance maintenance.

\section{Data Analysis}

All of the experimental sessions were analyzed daily using a discrete-trials performance verification form. This form presented all of the necessary steps to implement the procedure (e.g., obtaining the child's attention, presenting an instruction, waiting for a response, implementing correction or prompting procedures, recording data, and initiating the intertrial interval). The correct implementation of a given step produced one point on the verification form. Depending on the learning unit, some of the steps were not applicable (e.g., implementing correction steps was not applicable when a correct response was performed by the child). The level of implementation accuracy was determined by dividing the total number of correct implementations by the total number of implementations (correct and incorrect) and multiplying the quotient by 100 .

\section{Interobserver Agreement}

Thirty percent of the data that were recorded for each participant were checked by an independent observer who watched videos of the sessions and performed the implementation accuracy measurement. The level of interobserver agreement was determined by dividing the number of agreements by the total number of agreements and disagreements and multiplying the quotient by 100 . The overall interobserver agreement for this study was $98.3 \%$.

\section{Results}

All of the participants presented highly accurate implementation of the discrete-trials procedure after completing the present study. Beatriz underwent 15 data sessions. Eliana underwent 14 sessions. Vanessa underwent 10 sessions. Figure 1 shows the participants' performance accuracy while implementing the three teaching programs.

All of the participants presented stability during the baseline phase and increasing performance accuracy after introduction of the independent variable (video modeling). This pattern of data suggests that the intervention influenced the performance of all of the participants. The average performance accuracy after treatment $(93.5 \%$ for Vanessa, $100 \%$ for Eliana, and $100 \%$ for Beatriz) was higher than the average baseline accuracy (54.5\% for Vanessa, $45.5 \%$ for Eliana, and $65.5 \%$ for Beatriz). An upward trend in accuracy was observed after introducing the experimental treatment. This effect was immediate for Vanessa and Eliana and gradual for Beatriz.

Vanessa's performance increased from $0 \%$ in the first baseline session to $98 \%$ in the last postintervention session for Program 1 (Motor Imitation). For Program 2 (Intraverbal Using Personal Information), performance accuracy in the first baseline session was $62 \%$ and $97 \%$ in the last post-intervention session. In the generalization session, Vanessa presented 100\% performance accuracy while implementing the "Sitting" program, which was assigned to Daniel. In the follow-up session, Vanessa presented $97 \%$ implementation accuracy (Figure 1).

Eliana presented $22 \%$ accuracy at the beginning of baseline for Program 1, and she reached $100 \%$ accuracy in the last post-intervention session. For Program 2, her performance accuracy increased from $0 \%$ to $100 \%$ in the last post-intervention session. In the generalization phase, her performance accuracy was $100 \%$, which was partially maintained (93\%) after 1 month during the follow-up session.

Beatriz presented $57 \%$ accuracy in the first baseline session of Program 1 (Motor Imitation). Her accuracy increased to $100 \%$ in the last post-intervention session. For Program 2 (Personal Information Intraverbal), her performance accuracy increased from $68 \%$ in the last baseline session to $100 \%$ in the last post-intervention session. In the generalization phase, Beatriz presented $100 \%$ accuracy while 


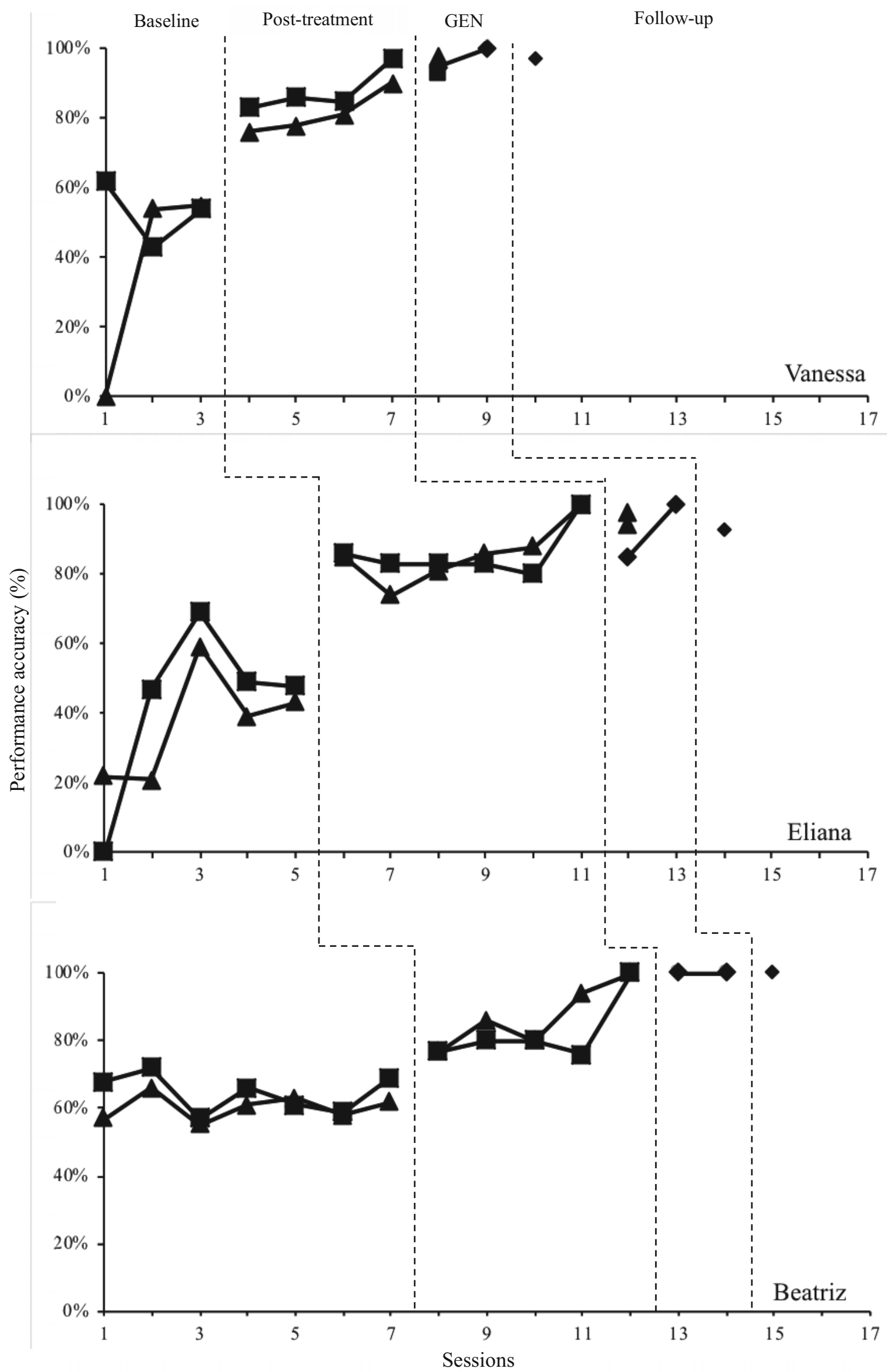

Figure 1. Performance accuracy of the participants Vanessa, Eliana, and Beatriz at baseline, post-intervention, generalization (GEN), and follow-up. 
implementing the "Tact of actions" program, which was assigned to Luan. In the last followup session, her performance was maintained at 100\% (Figure 1).

Figure 2 shows the workload for each participant during training. An average 3-hour workload was necessary for the participants to complete the intervention. Beatriz was given 88 minutes of baseline measurement, 104 minutes of video modeling, and 18 minutes of feedback. Vanessa was given 96 minutes of baseline measurement, 84 minutes of video modeling, and 5 minutes of feedback. Eliana was given 169 minutes of baseline measurement, 150 minutes of video modeling, and 19 minutes of feedback.

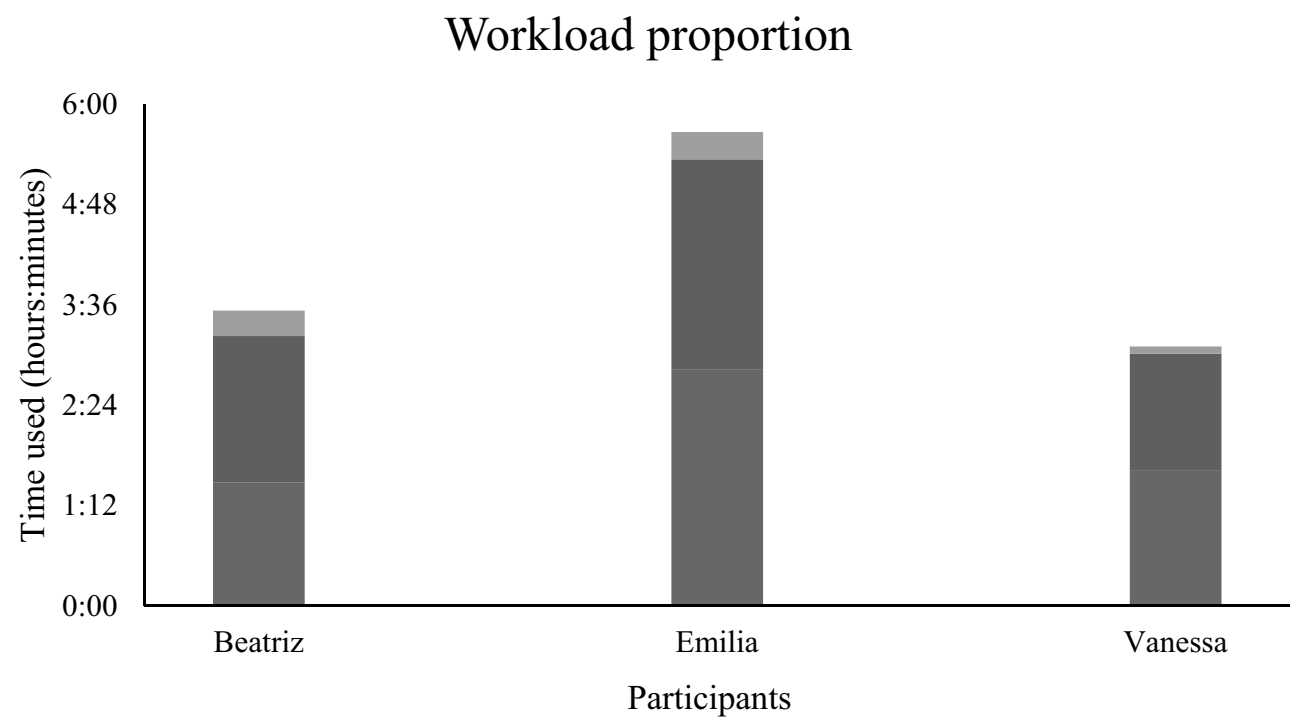

Figure 2. Workload required for each participant at baseline (Blue), instructional video modeling (Red), and feedback (Green) sessions.

The present data generally show that the independent variable (i.e., instructional video modeling) had a clear and significant positive impact on implementation accuracy for all of the participants. Beatriz's accuracy increased from $62.5 \%$ in the first baseline session to $100 \%$ in the last post-intervention session. Eliana's accuracy increased from $11 \%$ to $100 \%$. Vanessa's accuracy increased from $31 \%$ to $93.5 \%$. Figure 2 shows that the workload that was necessary to conduct this procedure (an average of 3 hours) was even less than the workload that was reported by Barboza et al. (2015), which was an average of 5 hours.

\section{Discussion}

The present study confirmed findings on the efficacy and efficiency of instructional video modeling procedures to teach discretetrials procedures to parents or caregivers (e.g.,
Barboza et al., 2015). Such training technology is an alternative way to advance behavioranalytic interventions for ASD under costlimited con-ditions. The limitations of the experimental control that were highlighted by Barboza et al. (2015) were successfully overcome in the present study, in which we conducted a progressively greater number of baseline sessions across participants to adhere to a multiple-baseline design.

Performance accuracy increased specifically after instructional video modeling and before any feedback was given, thus encouraging the use of such a procedure to teach parents of children who are diagnosed with ASD how to implement discrete-trial procedures and showing that little additional support or feedback is needed to achieve training goals. These data demonstrate an effective way to promote interventions. Such efficiency that is conferred by parents consequently reduces the 
time that a behavior analyst needs to dedicate to implementation so that the behavior analyst can focus more time on assessing the child's repertoire, designing teaching programs, and monitoring the child's progress and implementation accuracy.

More importantly, this kind of teaching tool can reach its full potential only when it is part of a wider training program that involves behavior analyst presence-based interactions in a comprehensive intervention approach. Parental training that uses instructional video modeling is among other tools that can be utilized by behavior analysts to increase the potential of interventions to produce necessary behavioral changes, particularly when hiring technical personnel is not an option.

\section{References}

Baio J, Wiggins L, Christensen DL, et al. Prevalence of Autism Spectrum Disorder Among Children Aged 8 Years - Autism and Developmental Disabilities Monitoring Network, 11 Sites, United States, 2014. MMWR Surveill Summ 2018;67(No. SS-6):1-23. doi: http://dx.doi. org/10.15585/mmwr.ss6706a1

Barboza, A. A., Silva, A. J. M., Barros, R. S., \& Higbee, T. S. (2015). Efeitos de videomodelação instructional sobre o desempenho de cuidadores na aplicação de programas de ensino a crianças diagnosticadas com autismo. Acta Comportamentalia, 23, 405-421.

Borba, M. M. C. (2014). Intervenção ao autismo via cuidadores (Doctoral dissertation, Universidade Federal do Pará, Belém, PA, Brazil). Retrieved from http://ppgtpc.propesp.ufpa.br/ ARQUIVOS/teses/Marilu\%20Borba\%202014. pdf

Catania, C. N., Almeida, D., Liu-Constant, B., \& DiGennaro-Reed,F.D.(2009). Video modeling to train staff to implement discrete-trial instruction. Journal of Applied Behavior Analysis, 42, 387392. doi: 10.1901/jaba.2009.42-387

Faggiani, R. B. (2014). Análise de componentes de um tutorial computadorizado para ensinar a realização de tentativas discretas (Doctoral dissertation, Universidade de São Paulo, São Paulo, SP, Brazil). Retrieved from http://www. teses.usp.br/teses/disponiveis/47/47132/tde27032015-124725/pt-br.php

Fazzio, D. (2007). Training tutors and parents to implement discrete-trials teaching with children diagnosed with autism (Doctoral dissertation). Department of Psychology, University of Manitoba, Winnipeg, Canada. Retrieved from https://mspace.lib.umanitoba.ca/ handle/1993/2965

Ferreira, L. A., Silva, A. J. M., \& Barros, R. S. (2016). Ensino de aplicação de tentativas discretas a cuidadores de crianças diagnosticadas com autismo. Perspectivas em Análise do Comportamento, 7, 101-113. doi: 10.18761/ pac. 2015.034

Horrocks, E. L. (2010). The effects of in-service teacher training on correct implementation of assessment and instructional procedures for teachers of individuals with profound multiple disabilities (Doctoral dissertation). Utah State University, Logan, UT. Retrieved from https:// digitalcommons.usu.edu/cgi/viewcontent. cgi article $=1583 \&$ context $=$ etd

Lovaas, O. I. (1987). Behavioral treatment and normal educational and intellectual functioning in young autistic children. Journal of Consulting and Clinical Psychology, 55, 3-9. doi: 10.1037/0022-006x.55.1.3

Marcus, A., \& Wilder, D. A. (2009). A comparison of peer video modeling and self video modeling to teach textual responses in children with autism. Journal of Applied Behavior Analysis, 42, 335341. doi: 10.1901/jaba.2009.42-335

National Autism Center. (2009). Evidence-based practice and autism in the schools: A guide to providing appropriate interventions to students with autism spectrum disorders. Randolph, MA: Author. Retrieved from http://www.pbis.org/ Common/Cms/files/Forum14_Presentations/ D15_NAC_Ed_Manual_FINAL.pdf

Nelson-Head, C., Hill, D., \& Flores, M. (2012). Case study on the implementation of a video storybased intervention with self-modeling treatment package to reduce stereotypical spitting behavior in a young girl with autism. Journal of Special Education and Rehabilitation, 13(3-4), 85-98. doi: 10.2478/v10215-011-0027-1

Nielsen, D., Sigurdsson, S. O., \& Austin, J. (2009). Preventing back injuries in hospital settings: The effects of video modeling on safe patient lifting 
by nurses. Journal of Applied Behavior Analysis, 42, 551-561. doi: 10.1901/jaba.2009.42-551

O'Dell, S. (1974). Training parents in behavior modification: A review. Psychological Bulletin, 81, 418-433. doi: 10.1037/h0036545

Plavnick, J. B., \& Ferreri, S. J. (2011). Establishing verbal repertoires in children with autism using function-based video modeling. Journal of Applied Behavior Analysis, 44, 747-766. doi: 10.1901/jaba.2011.44-747

Pollard, J. S., Higbee, T. S., Akers, J. S., \& Broadhead, M. T. (2014). An evaluation of interactive computer training to teach instructors to implement discrete trials with children with autism. Journal of Applied Behavior Analysis, 47, 765-776. doi: 10.1002/jaba.152

Sallows, G. O., \& Graupner, T. D. (2005). Intensive behavioral treatment for children with autism: Four-year outcome and predictors. American Journal on Mental Retardation, 110, 417-438. https://doi.org/10.1177/1362361301005004007
Sundberg, M. L. (2014). Verbal Behavior Milestones Assessment and Placement Program: A language and social skills assessment program for children with autism or other developmental disabilities (2nd Ed.). Concord, CA: AVB Press.

Vladescu, J. C., Carroll, R., Paden, A., \& Kodak, T. M. (2012). The effects of video modeling with voiceover instruction on accurate implementation of discrete-trial instruction. Journal of Applied Behavior Analysis, 45(2), 419-423. doi: 10.1901/jaba.2012.45-419

Watson, P. J., \& Workman, E. A. (1981). The nonconcurrent multiple baseline across-individuals design: An extension of the traditional multiple baseline design. Journal of Behavior Therapy and Experimental Psychiatry, 12(3), 257-259. https://doi.org/10.1016/0005-7916(81)90055-0

Received: $12 / 04 / 2018$

$1^{\text {st }}$ revision: $30 / 10 / 2018$

$2^{\text {nd }}$ revision: $24 / 11 / 2018$

Accepted: 02/12/2018

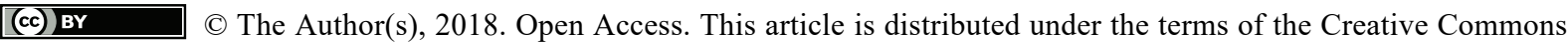
Attribution 4.0 International License (http://creativecommons.org/licenses/by/4.0/), which permits unrestricted use, distribution, and reproduction in any medium, provided you give appropriate credit to the original author(s) and the source, provide a link to the Creative Commons license, and indicate if changes were made. 